\title{
VALIDITY AND RELIABILITY OF LEARNING MOTIVATION INSTRUMENT (I-MABAR) STUDENTS IN ONLINE LEARNING DURING COVID 19
}

\author{
Bachrizal Bakhtiar \\ Universiti Pendidikan Sultan Idris \\ bachrizalswot@gmail.com
}

\begin{abstract}
This article aims to determine the validity of the construction and reliability of a learning motivation instrument (I-MABAR) of students in the time of covid pandemic 19. Researchers used a pilot study on 36 students of Universiti Pendidikan Sultan Idris (UPSI) as a sample to obtain reliability, and three supervisors to obtain validity. Researchers have developed a questionnaire with a google form that contains a total of 24 items. Student learning motivation should be measured to ensure the level of student learning motivation in the learning process in the current Covid-19 dememic. For that, there needs to be a learning motivation instrument that has a good degree of validity and reliability to get the right display of student learning motivation. The findings of the study show that 24 instrument items from the five main constructs of I-MABAR have a very high total item correlation value. However, there are two total instrument items that have a strong correlation value namely items D3 and E1. But all items have an acceptable validity value. While the findings of reliability values using Cronbach Alpha analysis have a very high value. Thus, the validity and reliability of the instrument shows that the student learning motivation instrument (I-MABAR) has a quality that can be used to measure learning motivation
\end{abstract}

Keywords: Validity and reliability, learning motivation instrument, online

Received 31 January 2021 Accepted 31 January 2022

\section{INTRODUCTION}

Technological advances can be of great potential in various fields, especially in the field of education. Therefore, this can be perceived positively and adaptively in responding to the challenges of the 21st century which is full of complexity (Aziz Hussin, 2018; Gamar et al., 2018). The use of technology in education has become a very important issue and is often discussed in various activities (Orgaz et al., 2018 \& Traxler, 2018), the existence of technology in the world of education is a method that can be used as a medium to deliver good learning programs both as an interactive (Husaini, 2014), the learning process is no longer limited by certain classrooms (Denker, 2013), besides the use of technology has enabled the emergence of distance learning and encouraged greater innovation in creating teaching methods in and outside the classroom (Almeida \& Simoes, 2019).

Online learning is an educational innovation that involves technological elements in learning. According to Mustafa et al (2019) that online learning is a distance education system with a set of teaching methods where there are teaching activities carried out separately from learning activities. Online learning is organized through internet and web 2.0 networks, which means that the use of online learning involves technological elements as tools and internet networks as systems (Alessandro, 2018). Online learning has been widely conducted in the context of higher education, as evidenced by several studies explaining this (Crews \& Parker, 
2017; Mather \& Sarkans, 2018), online learning provides benefits in helping provide access to learning for everyone, thus eliminating physical barriers as a factor for learning within the scope of the classroom (Riaz, 2018), in fact this is seen as something that is effective to apply, especially in higher education. However, according to Pilkington (2018) it is undeniable that not all learning can be transferred to the online learning environment.

A new disease that has never been identified before in humans is Coronavirus 2019 (Covid-19), on January 30, 2020 the WHO has declared it a world-leading public health emergency (Zhou et al., 2020). The Covid-19 pandemic is a multi-dimensional problem facing the world, it also affects the education sector which causes a decrease in the quality of learning in students (Sahu, 2020), this pandemic emergency needs a learning system replaced with online learning until the learning process continues (, 2020), this clearly changes the pattern of learning that requires teachers and educational developers to provide learning materials and teach students directly through remote digital tools (United Nations, 2020). Online learning allows students to have the flexibility to learn, so they can learn anytime and anywhere.

In addition, students can interact with lecturers using several applications such as eclassroom, video conference, google meet, zoom or through WhatsApp group (Dhull \& Sakshi, 2017). This learning activity is an educational innovation to answer the challenges of the existence of various learning resources. The success of a learning model or media depends on the characteristics of the student. This is stated by Nakayama et al (2014) that all literature shows that not all students will be successful in online learning, this is due to differences in learning environment factors and student characteristics. One of the successes in learning is related to student motivation (Schunk et al., 2014).

According to Brophy (2010) that motivation is the construction of theories to explain initiation, direction, intensity, persistence, and quality of behavior, especially behavior directed at purpose. Motivation gives impetus for action aimed at the desired direction both physically and mentally, so that activity becomes a very important part of motivation (Lee \& Martin, 2017). Motivation can influence what we learn, how we learn, and when we choose to learn (Schunk \& Usher, 2012). This is also shown by research that explains that motivated students tend to do challenging activities, actively engage, enjoy the process of learning activities and show improved learning outcomes, perseverance and creativity (Samir Abou El-Seoud et al., 2014), In addition., designing a learning environment that motivates students can attract students (Keller, 2010).

According to Selvi (2010), online learning is often needed to be more motivated because the learning environment usually relies on motivation and characteristics related to curiosity and self-regulation to engage the learning process. In fact, technology itself is seen by some as an inherent motivation because it provides a number of qualities that are recognized as important in cultivating intrinsic motivation, namely challenge, curiosity, innovation and fantasy (Lepper et al., 2005; Lin et al., 2008) . Motivation is considered an important factor for learning success including in online learning environment, so it is necessary to reconsider learning motivation in learning environment using technology (Harandi, 2015). Therefore, it is important for researchers in the world of education to study in depth how student motivation in online learning especially learning activities are carried out during the Covid-19 Pandemic. The aspects studied in this study are related to the aspects explained by Hamzah B. Uno (2007) who wrote 5 indicators of learning motivation, namely focus, curiosity, enthusiasm, freedom, readiness, enthusiasm or support, never give up , and confident.

Student learning motivation should be measured to ensure the level of student learning motivation in the learning process in the current Covid-19 dememic. For that, there needs to be a learning motivation instrument that has a good degree of validity and reliability to get the right display of student learning motivation. Therefore, there is a need to create a learning motivation instrument based on theory that can be used in the context of matching education 
in general, especially at the Sultan Idris University of Education (UPSI). The study objects in this study are determine the validity of the Learning Motivation Instrument (I-MABAR) construct and determining the reliability of Learning Motivation Instruments (I-MABAR).

\section{METHODOLOGY}

\section{Study Design}

The approach of this study is a quantitative approach. The design of this study is a survey study using question search method. This form of study was chosen after taking the views of scholars who say that research studies that use well-known research questions in the field of education due to the factor of trying to study almost all problems and problems, become efficient and save time and money (Creswell 2017).

\section{Sampling}

This pilot study involved 36 students from Sultan Idris University of Education (UPSI) as a sample of the study. The sampling technique used is simple sampling, that is, not random sampling, as it takes into account the suitability and readiness of students to answer research questions. This sampling technique was chosen because it is suitable for cloning studies, preliminary analysis and aims to provide a rough overview of the phenomena found in the study population and guide researchers through in-depth studies (Cresswell 2005). The study sample is limited to students at UPSI only. The research technique used is through the circulation of search questions using google form.

\section{Instruments}

In this study, the researcher has changed the instrument developed by Maknunatin E. (2010), which is an instrument to measure learning motivation. The selection of this instrument is to determine the validity and reliability of the learning motivation instrument for students in the current Coved-19 pandemic. The first part of the instrument contains items related to the background of the sample such as gender, semester age and program / course. The second part discusses the Learning Motivation Instrument (I-MABAR) which represents twenty-four items instead of the five main constructs. Table 1 shows the constructs that were altered through literature review.

Table 1: Summary of number of items by construct

\begin{tabular}{clcc}
\hline No & \multicolumn{1}{c}{ Construct } & Item & No. Item \\
\hline $\mathbf{1}$ & There is a desire to Succeed & $1-5$ & 5 \\
\hline $\mathbf{2}$ & There are motivations and needs in learning & $5-10$ & 5 \\
\hline $\mathbf{3}$ & There are hopes and dreams for the future & $11-15$ & 5 \\
\hline $\mathbf{4}$ & There is an appreciation in learning & $15-20$ & 5 \\
\hline $\mathbf{5}$ & There are interesting activities in learning & $21-24$ & 4 \\
\hline
\end{tabular}

For the measurement of the Learning Motivation instrument (I-MABAR), a fivepoint Likert scale was used, as shown in Table 2 below.

Table 2: Content Measurement Scale of Learning Motivation Instrument (I-MABAR) 12

45

Strongly disagree Do not agree Not sure Agree Strongly agree


The choice of 5 point scale is because not too little and not too much. According to Chua Y. (2014), the advantages of Likert scale are easy to manage and use, items are easy to answer by respondents and the data collected has higher reliability than other scales such as Thurstone and Guttman. In addition, too much scale will make it difficult for respondents to differentiate and will provide a lot of disruption in the validity of data scores (Kelly \& Kenneth, 2006; Linacre, 2005; and Fleiss, 1971).

There is no neutral choice because respondents are given the option to leave an answer if they are not confident in their choice. Findings of the validity of the instrument construct, analyzed by comparing the validity results according to the interpretation of the coefficients shown in the table below:

Table 3: Correlation Values and Relationship Strength Levels

\section{Correlation Coefficient Value Coefficient Interpretation}

\begin{tabular}{cl}
\hline $0.01-0.09$ & Boleh diabaikan \\
\hline $0.10-0.29$ & Rendah \\
\hline $0.30-0.49$ & sederhana kuat \\
\hline $0.50-0.69$ & Kukuh \\
\hline $0.70-0.99$ & Sangat tinggi \\
\hline 1.00 & Sempurna \\
\hline
\end{tabular}

Sumber: Davies, I.I.C (dalam Ghazali D \& Sufean H. 2018)

Next, on the results of the reliability of the instrument, will be interpreted according to the interpretation proposed by Dermoott \& Sarrela (in Ghazali D \& Sufean H. 2018), where the high alpha value index score (skor) $a=.65$ to .95 has high reliability . On the other hand if the value of low alpha coefficient $a=.60$ indicates the level of ability of the study instrument item to measure constructs or concepts in the study is low.

\section{Data analysis}

All data obtained from the questionnaire will be analyzed using SPSS Computer Program 23.0 (Statistical Package for Social Science 23.0).

Data analysis is done according to the set objectives of the study, such as the objectives of the study:

a) Determining the validity of the Learning Motivation Instrument (I-MABAR) construct. The objectives of this study will be analyzed using Bivariate Correlation analysis, meaning to determine the correlation between items and items and between items with total score.

b) Determining the Reliability of Learning Motivation Instruments (I-MABAR). The objectives of this study, will be analyzed using Cronbach's alpha analysis. Cronbach's Alpha procedure is used to calculate the reliability coefficients of the questionnaire items through internal consistency rates (Ghazali D. \& Sufean H., 2018). Cronbach's Alpha coefficient can also be used to measure the reliability of an instrument if 5 Likert scales from ordinal data are used.

\section{FINDINGS}

This section of researchers reports the findings of a pilot study analysis related to the validity and reliability of the Student Learning Motivation instrument at the time of the coved-19 pandemic.

\section{Validity of Student Learning Motivation Instrument (I-MABAR)}


Findings of the correlation value of each item from each construct, can be seen in the total score. This can be seen through table 4 , table 5 , table 6 , table 7 , table 8 as follows:

Table 4: Correlation Value of Constructed Items There is a Desire to Succeed

\begin{tabular}{ccccccc}
\hline Item & B1 & B2 & B3 & B4 & B5 & Total B \\
\hline B1 & 1 & & & & & .759 \\
\hline B2 & .658 & 1 & & & & .900 \\
\hline B3 & .475 & .731 & 1 & & & .812 \\
\hline B4 & .582 & .705 & .655 & 1 & & .862 \\
\hline B5 & .418 & .619 & .513 & .583 & 1 & .773
\end{tabular}

Based on the calculation of the validity results of the construct shown in table 4, using the analysis of Bivariate Correlation assisted SPSS version 23. It is known that the correlation value of the total of each item with significance level 0.01 and 0.05 level (2-tailed) is .759 to 900. This indicates that all items in this instrument have a very high validity value and are within an acceptable range of values.

Table 5: Correlation Values of Constructed Items There are Encouragement and Needs in Learning

\begin{tabular}{ccccccc}
\hline Item & C1 & C2 & C3 & C4 & C5 & Total C \\
\hline C1 & 1 & & & & & .789 \\
\hline C2 & .726 & 1 & & & & .902 \\
\hline C3 & .612 & .725 & 1 & & & .870 \\
\hline C4 & .515 & .734 & .669 & 1 & & .855 \\
\hline C5 & .417 & .573 & .588 & .637 & 1 & .753 \\
\hline
\end{tabular}

The table above shows that the correlation value of the total of each item with a significance level of 0.01 and 0.05 level (2-tailed) is .753 to .902. This indicates that all items in this instrument have a very high validity value and are within an acceptable range of values.

Table 6: Correlation Values of Constructed Items There are Hopes and Dreams for the Future

\begin{tabular}{ccccccc}
\hline Item & D1 & D2 & D3 & D4 & D5 & Total D \\
\hline D1 & 1 & & & & & .844 \\
\hline D2 & .725 & 1 & & & & .830 \\
\hline D3 & .318 & .271 & 1 & & & .595 \\
\hline D4 & .505 & .582 & .161 & 1 & & .700 \\
\hline D5 & .545 & .498 & .396 & .308 & 1 & .716 \\
\hline
\end{tabular}

The table above shows that the correlation value of each total item with significance level 0.01 and 0.05 level (2-tailed). In item D3 is .595. This indicates a strong, yet acceptable, correlation value. While at the total value of items $\mathrm{D} 1=.885, \mathrm{D} 2=.830, \mathrm{D} 4=.700$ and D5 $=$ .716. This indicates a very high validity value and is within an acceptable range of values.

Table 7: Construction Item Correlation Values There Is Appreciation In Learning 


\begin{tabular}{ccccccc}
\hline Item & E1 & E2 & E3 & E4 & E5 & Total E \\
\hline E1 & 1 & & & & & .590 \\
\hline E2 & .385 & 1 & & & & .833 \\
\hline E3 & .370 & .629 & 1 & & & .858 \\
\hline E4 & .411 & .616 & .697 & 1 & & .852 \\
\hline E5 & .086 & .588 & .639 & .597 & 1 & .744 \\
\hline
\end{tabular}

The table above shows that the correlation value of each total item with significance level 0.01 and 0.05 level (2-tailed). In item E1 is .590. This indicates a strong, yet acceptable, correlation value. While at the total value of items $\mathrm{E} 2=.833, \mathrm{E} 3=.858, \mathrm{E} 4=$ .852 and $\mathrm{E} 5=.744$. This indicates a very high validity value and is within an acceptable range of values.

Table 7: Correlation Values of Constructed Items There Are Interesting Activities in Learning

\begin{tabular}{cccccc}
\hline Item & F1 & F2 & F3 & F4 & Total F \\
\hline F1 & 1 & & & & .889 \\
\hline F2 & .751 & 1 & & & .739 \\
\hline F3 & .676 & .519 & 1 & & .820 \\
\hline F4 & .328 & .144 & .316 & 1 & .622 \\
\hline
\end{tabular}

The table above shows that the correlation value of each total item with a significance level of 0.01 (2-tailed). At the total value of items $\mathrm{F} 1=.889, \mathrm{~F} 2=.739$, and $\mathrm{F} 3=.820$. This indicates a very high validity value and is within an acceptable range of values. While the F4 item is .622. This indicates a strong, yet acceptable, correlation value.

\section{Reliability of Learning Motivation Instruments (I-MABAR)}

The findings of the pilot study analysis related to the reliability of the Student Learning Motivation instrument at the time of the coved-19 pandemic.

Table 8: Findings of Instrument Reliability Analysis of each construct item

\begin{tabular}{ccc}
\hline Instrumen & Crobach's Alpha & Interpretasi \\
\hline Learning Motivation & .944 & High \\
Instrument (I-MABAR) & & \\
\hline
\end{tabular}

Based on table 8 above, it shows that Cronbach's Alpha Value for all constructs in the Learning Motivation Instrument (I-MABAR) shows a high reading of .944. This shows that all items in this instrument have good reliability values and are in the accepted range.

\section{DISCUSSION}

The validity and reliability of the instrument is very important to maintain accuracy from being exposed to defects. The higher the value and level of validity and reliability of the instrument the more accurate the data will be obtained to produce a good and quality study (Ghazali D. \& Sufean H., 2018).

I-MABAR stands for Learning Motivation Instrument. I-MABAR is an adapter for learning motivation items according to the student learning process during the Covid-19 pandemic. Initially, this instrument has passed the expert approval stage, which means that the instrument items are suitable for use. Next, the validity and reliability of the MABAR instrument was tested through a pilot study involving 36 students at UPSI and the analysis 
process using Bivariate Correlation analysis, to find the validity value of the construct. As for finding the reliability value using Cronbach Alpha analysis.

The main objective of this study is to determine the validity and reliability of learning motivation instrument (I-MABAR). The findings of the study show that 24 instrument items from the five main constructs of I-MABAR have a very high total item correlation value. However, there are two total instrument items that have a strong correlation value namely items D3 and E1. But all items have an acceptable validity value. While the findings of reliability values using Cronbach Alpha analysis have very high values. In accordance with the interpretation proposed by Dermoott \& Sarrela (in Ghazali D. \& Sufean H. 2018). Therefore, the learning motivation instrument (I-MABAR) for students in online learning on Covid-19 has fulfilled its validity and reliability well.

These findings are in line with the study conducted by Ni Putu Aprilia K. et al 2020. which aims to develop learning motivation assessment instruments in IPA subjects. Found excellent validity value, namely .85 and high reliability i.e. .80. This study is also supported by a study conducted by Sagitasari (2010) and Winda A. (2020) which uses Bivariate Correlation analysis as a validity test and Alpha Cronbach as a test instrument reliability test.

\section{SUMMARY}

The pilot study conducted can conclude that validity and reliability are among the important aspects and should be conducted before building a new instrument. This is because a valid instrument will be formed to allow the measurement to be measured with the desired accuracy. To be sure, fine instruments were found to show better reliability features.

The validity and reliability of the instrument indicates that the student learning motivation instrument (I-MABAR) has qualities that can be used to measure learning motivation. The implications of this study are expected to provide contributions and guidance to investigators or educators who want to develop a truly fair and accurate measurement instrument. As well as being able to assist other reviewers in developing student learning motivation instruments according to the current situation during the Covid-19 period.

\section{REFERENCES}

[1] Alessandro, B. (2018). Digital Skills and Competence, and Digital and Online Learning. Turin: European Training Foundation.

[2] Almeida, F., \& Simoes, J. (2019). The Role of Serious Games, Gamification and Industry 4.0 Tools in the Education 4.0 Paradigm. Contemporary Educational Technology, 10(2), 120-136. https://doi.org/10.30935/cet.554469.

[3] Aziz Hussin, A. (2018). Education 4.0 Made Simple: Ideas For Teaching. International Journal of Education and Literacy Studies, 6(3), 92-98. https://doi.org/10.7575/aiac.ijels.v.6n.3p.92.

[4] Brophy, J. (2010). Motivating Students to Learn (3th Ed). Routledge, Abingdon-onThames. Creswell, J. W. (2010). Research Design: Pendekatan Kualitatif, Kuantitatif, dan Mixed. Yogyakarta: Pustaka Pelajar.

[5] Crews, J., \& Parker, J. (2017). The Cambodian Experience: Exploring University Students' Perspectives for Online Learning. Issues in Educational Research, 27(4), 697719.

[6] Denker, K. J. (2013). Student Response Systems and Facilitating the Large Lecture Basic Communication Course: Assessing Engagement and Learning. Communication Teacher, 27(1), 50-69. https://doi.org/10.1080/17404622.2012.730622.

[7] Dhull, I., \& Sakshi. (2017). Online Learning. International Education \& Research Journal (IERJ), 3(8), 32-34. 
[8] Gamar, M. M., Al Faruq, M. S., \& Lina, L. (2018). Challenging the Indonesian Primary Education in Industrial Revolution 4.0 Era. 3rd International Conference on Education Management and Administration (CoEMA 2018), 269, 46-48. https://doi.org/10.2991/coema-18.2018.12.

[9] Hamzah B. Uno. (2009). Teori Motivasi dan Pengukurannya Analisis di Bidang Pendidikan. Jakarta: Bumi Aksara.

[10] Harandi, S. R. (2015). Effects of E-learning on Students' Motivation. Procedia - Social and Behavioral Sciences, 181, 423-430. https://doi.org/10.1016/j.sbspro.2015.04.905.

[11] Husaini, M. (2014). Pemanfaatan Teknologi Informasi dalam Bidang Pendidikan (EEducation). Jurnal Mikrotik, 2(1), 1-5.

[12] Keller, J. M. (2010). Motivational Design for Learning and Performance: The ARCS Model Approach. Spinger.

[13] Lee, J., \& Martin, L. (2017). Investigating Students' Perceptions of Motivating Factors of Online Class Discussions. International Review of Research in Open and Distance Learning, 18(5), 148-172. https://doi.org/10.19173/irrodl.v18i5.2883.

[14] Lepper, M. R., Corpus, J. H., \& Iyengar, S. S. (2005). Intrinsic and Extrinsic Motivational Orientations in the Classroom: Age Differences and Academic Correlates. Journal of Educational Psychology, 97(2), 184-196. https://doi.org/10.1037/0022-0663.97.2.184

[15] Lin, Y.-M., Lin, G.-Y., \& Laffey, J. M. (2008). Building a Social and Motivational Framework for Understanding Satisfaction in Online Learning. Journal of Educational Computing Research, 38(1), 1-27. https://doi.org/10.2190/EC.38.1.a.

[16] Mather, M., \& Sarkans, A. (2018). Student Perceptions of Online and Face-to-Face Learning. International Journal of Curriculum and Instruction, 10(2), 61-76.

[17] Mustofa, M. I., Chodzirin, M., Sayekti, L., \& Fauzan, R. (2019). Formulasi Model Perkuliahan Daring sebagai Upaya Menekan Disparitas Kualitas Perguruan Tinggi. Walisongo Journal of Information Technology, 1(2), 151. https://doi.org/10.21580/wjit.2019.1.2.4067.

[18] Nakayama, M., Mutsuura, K., \& Yamamoto, H. (2014). Impact of Learner's Characteristics and Learning Behaviour on Learning Performance during a Fully Online Course. Electronic Journal of E-Learning, 12(4), 394-408. www.ejel.org.

[19] Ni Putu Aprilia Krismony, Desak P. P.\& I Gusti N. J., (2020). Pengembangan Instrumen Penilaian untuk Mengukur Motivasi Belajar Siswa. Jurnal Ilmiah Pendidikan Profesi Guru Volume 3 Nomor 2 2020, pp 249-257

[20] Orgaz, F., Moral, S., \& Domínguez, C. (2018). Student's Attitude and Perception with the Use of Technology in the University. Journal of Educational Psychology $\begin{array}{lllll}\text { Propositos } & Y & \text { Representaciones, } & 6(2),\end{array}$ https://doi.org/http://dx.doi.org/10.20511/pyr2018.v6n2.230.

[21] Pilkington, O. A. (2018). Active Learning for an Online Composition Classroom: Blogging as an Enhancement of Online Curriculum. Journal of Educational Technology Systems, 47(2), 1-14. https://doi.org/10.1177/0047239518788278.

[22] Riaz, A. (2018). Effects of Online Education on Encoding and Decoding Process of Students and Teachers. International Conference E-Learning, 42-48. https://files.eric.ed.gov/fulltext/ED590288.pdf.

[23] Sahu, P. (2020). Closure of Universities Due to Coronavirus Disease 2019 (COVID-19): Impact on Education and Mental Health of Students and Academic Staff. Cureus, 2019(April). https://doi.org/10.7759/cureus.7541.

[24] Sagitasari, D. A. (2010). Hubungan Antara Kreativitas dan Gaya Belajar dengan Prestasi Belajar Matematika Siswa SMP. Universitas Negeri Yogyakarta, (September), 174.

[25] Samir Abou El-Seoud, M., Taj-Eddin, I. A. T. F., Seddiek, N., El-Khouly, M. M., \& Nosseir, A. (2014). E-learning and Students' Motivation: A Research Study on the Effect 
of Elearning on Higher Education. International Journal of Emerging Technologies in Learning, 9(4), 20-26. https://doi.org/10.3991/ijet.v9i4.3465.

[26] Schunk, D. H., Meece, J. R., \& Pintrich, P. R. (2014). Motivation in Education: Theory, Research, and Applications (4th Ed). Pearson.

[27] Schunk, D. H., \& Usher, E. L. (2012). Social Cognitive Theory and Motivation the Oxford handbook of Human Motivation (In RM Ryan). Oxford University Press.

[28] Selvi, K. (2010). Motivating Factors in Online Courses. Procedia - Social and Behavioral Sciences, 2(2), 819-824. https://doi.org/10.1016/j.sbspro.2010.03.110.

[29] Sintema, E. J. (2020). Effect of COVID-19 on the Performance of Grade 12 Students: Implications for STEM Education. Eurasia Journal of Mathematics, Science and Technology Education, 16(7), 1-6. https://doi.org/10.29333/ejmste/7893.

[30] Traxler, J. (2018). Distance learning-Predictions and possibilities. Education Sciences, 8 (1), 1-13. https://doi.org/10.3390/educsci8010035.

[31] Winda Ardyani, Aryo Andri Nugroho, Ali Shodiqin (2020). Instrumen angket gaya belajar visual, auditorial dan kinestetik untuk siswa SMP: validitas dan reliabilitas.

[32] Zhou, G., Chen, S., \& Chen, Z. (2020). Back to the Spring of Wuhan: Facts and Hope of COVID-19 Outbreak. Frontiers of Medicine, 14(2), 113-116. https://doi.org/10.1007/s11684-020-0758-9. 